\title{
BMJ Open Exposure to secondhand smoke from neighbours and respiratory symptoms in never-smoking adolescents in Hong Kong: a cross-sectional study
}

\author{
Lok Tung Leung, ${ }^{1}$ Sai Yin Ho, ${ }^{1}$ Man Ping Wang, ${ }^{2}$ Wing Sze Lo, ${ }^{1}$ Tai Hing Lam ${ }^{1}$
}

To cite: Leung LT, Ho SY, Wang MP, et al. Exposure to secondhand smoke from neighbours and respiratory symptoms in never-smoking adolescents in Hong Kong: a cross-sectional study. BMJ Open 2015;5:e008607. doi:10.1136/bmjopen-2015008607

- Prepublication history for this paper is available online. To view these files please visit the journal online (http://dx.doi.org/10.1136/ bmjopen-2015-008607).

Received 27 April 2015 Revised 4 July 2015 Accepted 31 July 2015

CrossMark

\footnotetext{
${ }^{1}$ School of Public Health, The University of Hong Kong, Hong Kong

${ }^{2}$ School of Nursing, The University of Hong Kong, Hong Kong
}

Correspondence to Dr Sai Yin Ho; syho@hku.hk

\section{ABSTRACT}

Objectives: To investigate secondhand smoke (SHS) exposure at home from neighbours in Hong Kong adolescents and its association with respiratory symptoms in never-smokers.

Design: A cross-sectional study.

Setting: 79 randomly selected secondary schools in Hong Kong.

Participants: 61810 secondary 1 (USA grade 7) to 7 students, in which 50762 never-smokers were identified and included in the analysis of the association between SHS exposure at home from neighbours and respiratory symptoms.

Main outcome measures: Smoking status, family smoking status, SHS exposure at home from inside the home and from neighbours in the past 7 days, respiratory symptoms and sociodemographic characteristics were reported. Adjusted ORs (AORs) of respiratory symptoms for SHS exposure from the 2 sources in never-smokers were calculated using logistic regression.

Results: In all students, $33.2 \%$ were exposed to SHS at home, including $16.2 \%$ from inside the home only, $10.0 \%$ from neighbours only and $7.0 \%$ from both. The prevalence of SHS exposure from neighbours was $17.1 \%$, including $13.5 \%$ for $1-4$ days/week and $3.6 \%$ for 5-7 days/week. In never-smokers ( $n=50762$ ), respiratory symptoms were significantly associated with SHS exposure from neighbours with AORs $(95 \%$ $\mathrm{Cl})$ of 1.29 (1.20 to 1.39$)$ for any exposure $(p<0.001)$, 1.21 (1.12 to 1.31$)$ for $1-4$ days/week $(p<0.001)$ and 1.63 (1.44 to 1.86) for $5-7$ days/week $(p<0.001)$ ( $P$ for trend $<0.001)$. Compared with no SHS exposure at home from any source, the AORs were 1.16 (1.07 to $1.25)$ for SHS from inside the home only $(p<0.001)$, 1.20 (1.11 to 1.31) from neighbours only $(p<0.001)$, and 1.74 (1.56 to 1.94$)$ from both $(p<0.001)$.

Conclusions: SHS exposure at home from neighbours was prevalent in Hong Kong adolescents, and was associated with respiratory symptoms in never-smokers. SHS exposure at home may be underestimated by ignoring the neighbouring source. Smoke-free housing policy is needed to protect children and adolescents from harms of SHS.
Strengths and limitations of this study

- The first study to investigate secondhand smoke exposure from neighbours and its association with respiratory symptoms in adolescents.

- Data were collected from a large and representative sample of Hong Kong adolescents with a high response rate.

- Causality could not be inferred due to the crosssectional design.

- Self-reported data were used.

\section{INTRODUCTION}

The respiratory effects of secondhand smoke (SHS) have been widely studied, supporting a causal relation between parental smoking and respiratory symptoms, including cough, phlegm, breathlessness and wheeze, in children aged 5-16 years. ${ }^{1}$ Still, nearly half the adolescents worldwide $(42.5 \%)$ were exposed to SHS at home. ${ }^{2}$ Furthermore, this only referred to smoking inside the home, ${ }^{2}$ ignoring a potential SHS source, smoking neighbours, whose SHS could drift to homes nearby through open windows and doors. ${ }^{13}$ Ventilation systems may reduce but not eliminate SHS exposure. ${ }^{4}$ Some Western studies have detected SHS transfer from smoking into non-smoking homes. ${ }^{35-7}$ In American children from non-smoking homes, higher exposure to SHS, as indicated by serum cotinine, was observed in those living in apartments than detached houses. ${ }^{7}$ The SHS transfer between units was greater for shorter interunit distance and poorer ventilation, as reflected by the elevated level of particulate matter with a diameter of less than $2.5 \mu \mathrm{m}$ $\left(\mathrm{PM}_{2.5}\right)$, a reliable indicator of SHS, ${ }^{8}$ in nonsmoking units. ${ }^{3}$ Since the measure of home SHS exposure in most studies, including the Global Youth Tobacco Survey (GYTS), ${ }^{2}$ is typically confined to SHS from inside the home, the prevalence is possibly underestimated, particularly in non-smoking families. 
Hong Kong is one of the most densely populated cities in the world $\left(6620\right.$ persons $\left./ \mathrm{km}^{2}\right) .{ }^{9}$ High-density housing with small dwelling units and narrow public corridors are common. ${ }^{10}$ The housing units in Hong Kong are on average much smaller $\left(45 \mathrm{~m}^{2}\right)$ than those in the USA $\left(174 \mathrm{~m}^{2}\right)$ and the UK $\left(85 \mathrm{~m}^{2}\right),{ }^{11}$ and windows and doors of neighbouring units are typically close to each other, ${ }^{12}$ facilitating the transfer of SHS between homes. Comprehensive smoke-free legislation in Hong Kong has prohibited smoking in most public indoor places, indoor areas of restaurants and workplaces, and some public outdoor places to protect the public against the harmful SHS. ${ }^{13}$ However, we have found an increase in home SHS exposure in children after the legislation, implying a displacement of smoking from public spaces to private homes, where smoking is not restricted by law. ${ }^{14}$ Complaints about SHS from neighbours are often heard and sporadic cases have been reported in the media, ${ }^{15}$ although the exposure prevalence has not been reported. The issue is of particular concern in public housing, a low-income multiunit housing accommodating $29.6 \%$ of the population. ${ }^{16}$ Since smoking is banned in all outdoor and shared indoor areas in these housing estates, ${ }^{17}$ smokers may resort to smoking at home, and the common practices of having the windows and doors open may facilitate SHS transfer.

Since there is no safe level of SHS exposure and even brief exposure can adversely affect health, ${ }^{1}$ the harms of SHS from neighbours may have been overlooked. We therefore investigated the prevalence of SHS exposure at home from neighbours in Hong Kong adolescents, and its association with respiratory symptoms in never-smokers.

\section{METHODS}

An anonymous survey was conducted in 2010/2011 in secondary 1 (USA grade 7) to 7 students from 79 schools randomly selected from all 18 districts in Hong Kong $(97.3 \%$ and $25.8 \%$ response rates at student and school levels, respectively) with a probability proportional to the total numbers of schools in the respective districts. An invitation letter was sent to parents via students, and declining parents could ask their children to return a blank answer sheet during the survey. Even with parental consent, student participation was totally voluntary. Ethical approval was granted by the Institutional Review Board of the University of Hong Kong/Hospital Authority Hong Kong West Cluster.

Students completed a questionnaire in classrooms where teachers maintained order without patrolling near them. Core questions including smoking status of the student and family, SHS exposure at home, and other smoking-related items were adapted from the GYTS with some modifications to suit local needs. ${ }^{2}$ Sociodemographic characteristics including age, sex, highest parental education and housing type, and respiratory symptoms were also asked. To encourage candid reporting, anonymity and confidentiality were emphasised, and an answer sheet was used to obscure the meaning of selected response options. The answer sheets were collected and sealed in front of the students by research staff on completion.

Students were asked to choose an option that best described their smoking status, namely 'I have never smoked', 'I have smoked once or a few times', 'I used to smoke occasionally, but have quit now', 'I used to smoke everyday, but have quit now', 'I occasionally smoke' and 'I smoke everyday', and to report the number of smoking days in the past 30 days. Those who simultaneously reported never smoking and not smoking in the past 30 days were defined as never-smokers, while those with inconsistent answers such as never smoking but having smoked in the past 30 days were excluded from analysis related to smoking status.

SHS exposure at home from smoking inside the home was assessed with the question 'In the past 7 days, on how many days have people smoked near you at home?', and that from smoking neighbours with the question 'In the past 7 days, how many days did you breathe in SHS at home that came from outside home (eg, neighbouring flats)?' For each of these two questions, response options ranged from 0 to 7 days and were recoded into ' 0 day/week' (reference), ' $1-4$ days/week' and ' $5-7$ days/week', with 'any exposure' representing any days of exposure per week. The answers were also combined to identify the sources of SHS at home, namely 'none' (reference), 'from inside home only', 'from neighbours only' and 'from both', with 'any source' representing SHS from either source.

Respiratory symptoms, an indirect indicator of SHS exposure dose, were asked using the question 'In the past 12 months, have you often coughed or had phlegm for 3 months in a row?' Similar measurements were used in previous studies on SHS exposure and respiratory symptoms in adolescents and children. ${ }^{14} 18 \quad 19$ The number of coresiding smokers was also reported. Families with one or more smokers, excluding the students, were classified as 'smoking families', and otherwise as 'non-smoking families'.

Excluding students $(0.4 \%)$ with missing information on age, sex or grade, or missing values for more than half of all items, 61810 remained for analysis. SPSS 20 and STATA 10 were used for data analysis. Descriptive results were weighted by age, sex and grade distribution of Hong Kong students in 2010/2011 provided by the government Education Bureau. Prevalence of SHS exposure at home, from inside the home and from neighbours, in all students and by family smoking status was calculated. Logistic regression was used to calculate adjusted ORs (AORs) of respiratory symptoms in neversmoking students for SHS exposure at home from inside the home and from neighbours as separate variables and combined, adjusting for age, sex, highest parental education, housing type and school clustering effect. To minimise the effects of any confusion over the two sources of SHS, subgroup analysis was conducted in never-smokers in non-smoking families. 


\section{RESULTS}

Total sample $(n=61810)$

The mean age (SD) of students was 14.7 (2.0) years. Table 1 shows that $50.8 \%$ of students were boys, $84.3 \%$ were never-smokers, $74.6 \%$ had parents attaining at least secondary education and $48.8 \%$ lived in public or subsidised housing. More than one-third of the students $(38.9 \%)$ lived with smokers, with the father $(70.3 \%)$, mother $(14.6 \%)$ and siblings $(11.0 \%)$ being the most common sources of SHS from inside the home.

Table 2 shows that the prevalence of SHS exposure from inside the home was $23.2 \%$, including $12.4 \%$ who were exposed for $1-4$ days and $10.8 \%$ for $5-7$ days/week. The corresponding prevalence of SHS exposure from neighbours was $17.1 \%, 13.5 \%$ and $3.6 \%$. Considering both sources, one-third (33.2\%) were exposed, including $16.2 \%$ from inside the home only, $10.0 \%$ from neighbours only and $7.0 \%$ from both. The corresponding figures were $66.4 \%, 42.7 \%, 6.8 \%$ and $17.0 \%$ in smoking families and $13.3 \%, 1.0 \%, 11.8 \%$ and $0.5 \%$ in non-smoking families.

Table 1 Basic characteristics of secondary 1-7 students

\begin{tabular}{|c|c|c|}
\hline $\begin{array}{l}\text { Basic } \\
\text { characteristics }\end{array}$ & $\begin{array}{l}\text { All } \\
(\mathrm{N}=61 \mathrm{810}) \\
\text { Per cent }\end{array}$ & $\begin{array}{l}\text { Never-smokers } \\
\text { ( } N=50762) \\
\text { Per cent }\end{array}$ \\
\hline \multicolumn{3}{|l|}{ Sex } \\
\hline Boys & 50.8 & 49.8 \\
\hline Girls & 49.3 & 50.2 \\
\hline \multicolumn{3}{|l|}{ Age group } \\
\hline$\leq 15$ & 66.1 & 68.1 \\
\hline$>15$ & 33.9 & 31.9 \\
\hline \multicolumn{3}{|c|}{ Highest parental education } \\
\hline Primary & 9.1 & 8.3 \\
\hline Secondary & 53.6 & 53.5 \\
\hline Tertiary & 21.0 & 22.2 \\
\hline $\begin{array}{l}\text { No formal } \\
\text { education }\end{array}$ & 1.2 & 1.0 \\
\hline Unknown & 15.2 & 15.0 \\
\hline \multicolumn{3}{|l|}{ Housing type } \\
\hline Public & 37.2 & 35.6 \\
\hline Subsidised & 11.6 & 11.9 \\
\hline Private & 37.7 & 39.5 \\
\hline Temporary & 1.4 & 1.0 \\
\hline Others/unknown & 12.2 & 12.0 \\
\hline \multicolumn{3}{|l|}{ Smoking family } \\
\hline No & 61.2 & 65.6 \\
\hline Yes & 38.9 & 34.4 \\
\hline \multicolumn{3}{|c|}{ Sources of SHS from inside the home } \\
\hline Father & 70.3 & 76.4 \\
\hline Mother & 14.6 & 11.8 \\
\hline Siblings & 11.0 & 6.1 \\
\hline Grandparents & 6.8 & 6.2 \\
\hline Other relatives & 6.9 & 7.0 \\
\hline Maid & 0.7 & 0.2 \\
\hline Other people & 4.6 & 3.4 \\
\hline
\end{tabular}

Percentages were weighted by age, sex and grade. SHS, secondhand smoke.

\section{Never-smoking students ( $\mathrm{n}=\mathbf{5 0} \mathbf{7 6 2})$}

In never-smokers, the mean age (SD) was 14.5 (2.0) years, $49.8 \%$ were boys (table 1 ), and $11.6 \%$ reported respiratory symptoms. Table 3 shows that $18.8 \%$ were exposed to SHS from inside the home, in which $14.2 \%$ had respiratory symptoms. SHS exposure from neighbours was reported by $15.0 \%$ of students, in which the prevalence of respiratory symptoms was also $14.2 \%$. In all the crude and adjusted logistic regression models, respiratory symptoms showed stronger associations for more days of SHS exposure, whether from inside the home or from neighbours. When adjusted for sociodemographic characteristics and school clustering effect (model 1 ), the AORs $(95 \% \mathrm{CI}$ ) of respiratory symptoms were 1.26 (1.17 to 1.35) for any SHS exposure from inside the home and 1.33 (1.23 to 1.43) from neighbours. After additionally adjusting for SHS from neighbours (model 2), the association between respiratory symptoms and SHS from inside the home remained significant, with AORs of 1.22 (1.14 to 1.31) for any exposure, 1.16 (1.06 to 1.27) for $1-4$ days and 1.28 (1.17 to 1.41) for 5-7 days ( $\mathrm{P}$ for trend $<0.001)$. Similarly, respiratory symptoms were significantly associated with SHS from neighbours when model 1 was further adjusted for SHS from inside the home (model 2), with AORs of 1.29 (1.20 to 1.39) for any exposure, 1.21 (1.12 to 1.31) for 1-4 days and 1.63 (1.44 to 1.86 ) for $5-7$ days ( $\mathrm{P}$ for trend $<0.001$ ).

Table 4 shows that in non-smoking families, respiratory symptoms were significantly associated with any days and 5-7 days of SHS exposure from neighbours, with AORs (95\% CI) of 1.18 (1.06 to 1.31$)$ and 1.58 (1.27 to 1.97$)$ ( $\mathrm{P}$ for trend $<0.001)$. In smoking families, stronger and significant associations were observed, with AORs of 1.47 (1.32 to 1.64 ) for any exposure, 1.39 (1.24 to 1.56 ) for $1-4$ days and 1.76 (1.44 to 2.14 ) for $5-7$ days ( $\mathrm{P}$ for trend $<0.001$ ).

Table 5 shows that in the crude analysis, exposure to SHS from either one or both sources was associated with respiratory symptoms in never-smoking students, compared with those unexposed. The associations remained significant after adjusting for sociodemographic characteristics and school clustering effects. The AORs (95\% CI) were 1.16 (1.07 to 1.25) for SHS from inside the home only and 1.20 (1.11 to 1.31) from neighbours only; a stronger association was observed for SHS exposure from both sources, with an AOR of 1.74 (1.56 to 1.94).

\section{DISCUSSION}

To the best of our knowledge, this survey is the first to investigate the SHS exposure from neighbours and its association with respiratory symptoms in adolescents. Close to one-fifth $(17.1 \%)$ of students were exposed to neighbour SHS. The exposure reported by students in non-smoking families was consistent with the biochemical and environmental evidence of SHS incursion from smoking into non-smoking homes in Western studies. ${ }^{3} 67$ Our results imply an underestimation of 
Table 2 Prevalence of SHS exposure at home by family smoking status

\begin{tabular}{|c|c|c|c|}
\hline & $\begin{array}{l}\text { All }(\mathrm{N}=61 \mathrm{810}) \\
\text { Per cent }\end{array}$ & $\begin{array}{l}\text { Smoking families } \\
(\mathrm{N}=22558) \\
\text { Per cent }\end{array}$ & $\begin{array}{l}\text { Non-smoking families } \\
\text { ( } \mathrm{N}=33344) \\
\text { Per cent }\end{array}$ \\
\hline \multicolumn{4}{|c|}{ SHS exposure at home (days/week) } \\
\hline \multicolumn{4}{|c|}{ From inside the home } \\
\hline 0 & 76.8 & 40.3 & 98.5 \\
\hline $1-4$ & 12.4 & 30.6 & 1.3 \\
\hline $5-7$ & 10.8 & 29.1 & 0.2 \\
\hline Any exposure & 23.2 & 59.7 & 1.5 \\
\hline \multicolumn{4}{|l|}{ From neighbours } \\
\hline 0 & 82.9 & 76.1 & 87.7 \\
\hline $1-4$ & 13.5 & 18.4 & 10.0 \\
\hline $5-7$ & 3.6 & 5.4 & 2.3 \\
\hline Any exposure & 17.1 & 23.9 & 12.3 \\
\hline \multicolumn{4}{|c|}{ Source of SHS exposure at home } \\
\hline None & 66.8 & 33.6 & 86.7 \\
\hline From inside the home only & 16.2 & 42.7 & 1.0 \\
\hline From neighbours only & 10.0 & 6.8 & 11.8 \\
\hline From both & 7.0 & 17.0 & 0.5 \\
\hline Any source & 33.2 & 66.4 & 13.3 \\
\hline
\end{tabular}

Percentages were weighted by age, sex and grade.

Number of students from smoking and non-smoking families did not add up to the total number of students due to missing data in reporting the number of coresiding smokers and data cleaning if inconsistency with another question about coresiding smoker identification was found. SHS, secondhand smoke.

SHS exposure at home if neighbour SHS is ignored. On the basis of our data, the underestimation would be $30.1 \%(10 / 33.2)$ in all students, $10.2 \%(6.8 / 66.4)$ in smoking families and, remarkably, $88.7 \%(11.8 / 13.3)$ in non-smoking families (table 2). Significant associations between SHS exposure from neighbours and respiratory symptoms were observed in smoking and non-smoking families (table 4). Since most studies investigating SHS at home in children and adolescents focused only on smoking in their own home, ${ }^{20-23}$ the burden of harms from SHS might be underestimated, especially in nonsmoking families, by overlooking SHS from neighbours. Ignoring SHS exposure from neighbours may also lead to an underestimation of the association between SHS

Table 3 Adjusted ORs of respiratory symptoms for number of days of SHS exposure at home in never-smoking students $(\mathrm{N}=50762)$

\begin{tabular}{|c|c|c|c|c|c|}
\hline \multirow[b]{2}{*}{$\begin{array}{l}\text { SHS at home } \\
\text { (days/week) }\end{array}$} & \multirow[b]{2}{*}{ N (\%) } & \multirow{2}{*}{$\begin{array}{l}\text { Respiratory } \\
\text { symptoms } \\
(\%)\end{array}$} & \multirow[b]{2}{*}{ Crude OR (95\% Cl) } & \multicolumn{2}{|l|}{ Adjusted OR (95\% Cl) } \\
\hline & & & & Model 1 & Model 2 \\
\hline \multicolumn{6}{|c|}{ From inside the home } \\
\hline 0 & 40575 (81.2) & 11.0 & 1 (reference) & 1 (reference) & 1 (reference) \\
\hline $1-4$ & $5295(10.1)$ & 13.7 & $1.21(1.11 \text { to } 1.32)^{\star \star \star}$ & $1.18(1.08 \text { to } 1.30)^{\star \star \star}$ & $1.16(1.06 \text { to } 1.27)^{\star *}$ \\
\hline $5-7$ & $4652(8.7)$ & 14.8 & $1.39(1.27 \text { to } 1.52)^{\star \star \star}$ & $1.34(1.22 \text { to } 1.47)^{\star * *}$ & $1.28(1.17 \text { to } 1.41)^{\star \star \star}$ \\
\hline$P$ for trend & - & - & $<0.001$ & $<0.001$ & $<0.001$ \\
\hline Any exposure & 9947 (18.8) & 14.2 & $1.29(1.21 \text { to } 1.38)^{\star \star \star}$ & $1.26(1.17 \text { to } 1.35)^{\star \star \star}$ & $1.22(1.14 \text { to } 1.31)^{\star * *}$ \\
\hline Per day increase & - & - & $1.05(1.04 \text { to } 1.07)^{\star \star *}$ & $1.05(1.03 \text { to } 1.06)^{\star * *}$ & $1.04(1.03 \text { to } 1.05)^{\star \star \star}$ \\
\hline \multicolumn{6}{|l|}{ From neighbours } \\
\hline 0 & 42924 (85.0) & 11.2 & 1 (reference) & 1 (reference) & 1 (reference) \\
\hline $1-4$ & $6148(12.1)$ & 13.4 & $1.23(1.14 \text { to } 1.33)^{\star \star \star}$ & $1.23(1.14 \text { to } 1.34)^{\star \star \star}$ & $1.21(1.12 \text { to } 1.31)^{\star \star \star}$ \\
\hline $5-7$ & $1503(2.9)$ & 17.2 & $1.74(1.52 \text { to } 1.99)^{\star \star *}$ & $1.72(1.51 \text { to } 1.95)^{\star \star \star}$ & $1.63(1.44 \text { to } 1.86)^{\star \star \star}$ \\
\hline$P$ for trend & - & - & $<0.001$ & $<0.001$ & $<0.001$ \\
\hline Any exposure & $7651(15.0)$ & 14.2 & $1.33(1.24 \text { to } 1.42)^{\star \star \star}$ & $1.33(1.23 \text { to } 1.43)^{\star \star \star}$ & $1.29(1.20 \text { to } 1.39)^{\star \star \star}$ \\
\hline Per day increase & - & - & $1.09(1.07 \text { to } 1.11)^{\star \star \star}$ & $1.09(1.07 \text { to } 1.11)^{\star \star \star}$ & $1.08(1.06 \text { to } 1.10)^{\star \star *}$ \\
\hline \multicolumn{6}{|c|}{$\begin{array}{l}\text { Percentages were weighted by age, sex and grade. } \\
\text { Model 1: Adjusted for age, sex, highest parental education, housing type and school clustering effect. } \\
\text { Model 2: Adjusted for variables in model } 1 \text { and mutually adjusted for SHS exposure from inside the home and from neighbours. } \\
{ }^{*} p<0.05,{ }^{\star *} p<0.01,{ }^{* \star *} p<0.001 \text {. } \\
\text { SHS, secondhand smoke. }\end{array}$} \\
\hline
\end{tabular}


Table 4 Adjusted ORs of respiratory symptoms for number of days of SHS exposure at home in never-smoking students by family smoking status

\begin{tabular}{|c|c|c|c|c|c|}
\hline \multirow{2}{*}{$\begin{array}{l}\text { SHS at home from } \\
\text { neighbourhood } \\
\text { (days/week) }\end{array}$} & \multirow[b]{2}{*}{ N (\%) } & \multirow{2}{*}{$\begin{array}{l}\text { Respiratory } \\
\text { symptoms } \\
(\%)\end{array}$} & \multirow[b]{2}{*}{ Crude OR $(95 \% \mathrm{Cl})$} & \multicolumn{2}{|l|}{ Adjusted OR (95\% Cl) } \\
\hline & & & & Model 1 & Model 2 \\
\hline \multicolumn{6}{|c|}{ Smoking families ( $N=16461)$} \\
\hline 0 & $13065(79.9)$ & 12.0 & 1 (reference) & 1 (reference) & 1 (reference) \\
\hline $1-4$ & $2627(16.0)$ & 16.3 & $1.39(1.23 \text { to } 1.56)^{\star \star \star}$ & $1.40(1.25 \text { to } 1.57)^{\star \star \star}$ & $1.39(1.24 \text { to } 1.56)^{\star \star \star}$ \\
\hline $5-7$ & $730(4.1)$ & 19.5 & $1.78(1.47 \text { to } 2.15)^{\star \star \star}$ & $1.78(1.47 \text { to } 2.17)^{\star \star \star}$ & $1.76(1.44 \text { to } 2.14)^{\star * *}$ \\
\hline$P$ for trend & - & - & $<0.001$ & $<0.001$ & $<0.001$ \\
\hline Any exposure & $3357(20.1)$ & 17.0 & $1.47(1.32 \text { to } 1.63)^{\star \star \star}$ & $1.48(1.33 \text { to } 1.65)^{\star \star \star}$ & $1.47(1.32 \text { to } 1.64)^{\star \star \star}$ \\
\hline Per day increase & - & - & $1.10(1.07 \text { to } 1.13)^{\star \star \star}$ & $1.11(1.08 \text { to } 1.13)^{\star \star \star}$ & $1.10(1.07 \text { to } 1.13)^{\star \star \star}$ \\
\hline \multicolumn{6}{|c|}{ Non-smoking families ( $\mathrm{N}=29677$ ) } \\
\hline 0 & $26076(87.8)$ & 10.5 & 1 (reference) & 1 (reference) & 1 (reference) \\
\hline $1-4$ & $2925(9.9)$ & 10.8 & $1.09(0.96$ to 1.23$)$ & $1.10(0.99$ to 1.23$)$ & 1.09 (0.98 to 1.22$)$ \\
\hline $5-7$ & $642(2.3)$ & 14.7 & $1.59(1.28 \text { to } 1.97)^{\star \star \star}$ & $1.60(1.29 \text { to } 2.00)^{\star \star \star}$ & $1.58(1.27 \text { to } 1.97)^{\star \star \star}$ \\
\hline$P$ for trend & - & - & $<0.001$ & $<0.001$ & $<0.001$ \\
\hline Any exposure & 3567 (12.2) & 11.5 & $1.17(1.05 \text { to } 1.31)^{\star \star}$ & $1.19(1.07 \text { to } 1.32)^{\star \star}$ & $1.18(1.06 \text { to } 1.31)^{\star *}$ \\
\hline Per day increase & - & - & $1.07(1.04 \text { to } 1.10)^{\star \star *}$ & $1.07(1.04 \text { to } 1.10)^{\star \star \star}$ & $1.07(1.04 \text { to } 1.10)^{\star \star \star}$ \\
\hline
\end{tabular}

exposure and respiratory symptoms by misclassifying exposed subjects as unexposed.

Under the high population density in Hong Kong, ${ }^{9}$ where homes are typically small and close to each other in multistorey housing, ${ }^{12}$ the potential problems brought by the SHS transfer between homes should not be neglected. We observed a dose-response relation between respiratory symptoms and SHS exposure at home from neighbours in never-smoking adolescents, in line with that for SHS exposure from inside the home in the present study and other studies among children and adolescents (tables 3 and 4). ${ }^{18}{ }^{24}$ The magnitudes of associations of respiratory symptoms were similar for SHS from neighbours only and SHS from inside the home only (table 5).

Adverse responses to airborne chemicals can be mediated through stress or biological mechanisms. ${ }^{25}$ The association of respiratory symptoms in students exposed to SHS at home from neighbours only might be explained by the stress-based response, which occurs due to perceived exposure risks when the concentration of chemicals lies between the odour detection and irritant thresholds. ${ }^{25}$ This group of students, unexposed to SHS from inside the home, might have their perceived risks of SHS affected by the no-smoking practice at home and the extensive antismoking promotions in Hong Kong, which denormalised smoking behaviours and disseminated information about the harms of smoking and SHS. Even though the concentration of SHS would be diminished during the incursion and lower than that of SHS generated in their own home, ${ }^{3}$ respiratory symptoms might be triggered as a stress-based response on exposure to neighbour SHS.

Besides concentration, frequency and duration also affect SHS exposure dose, which is closely related to respiratory symptoms. ${ }^{14}$ SHS incursion, especially in smoking-prevalent housing, probably occurred frequently so that students exposed to SHS from neighbours only and from inside the home only might have

Table 5 Adjusted ORs of respiratory symptoms for different sources of SHS exposure at home in never-smoking students $(\mathrm{N}=50$ 762)

\begin{tabular}{|c|c|c|c|c|}
\hline Sources of SHS at home & $\mathbf{N}(\%)$ & $\begin{array}{l}\text { Respiratory } \\
\text { symptoms (\%) }\end{array}$ & Crude OR (95\% Cl) & Adjusted OR $(95 \% \mathrm{Cl})$ \\
\hline None & $35301(70.8)$ & 10.8 & 1 (reference) & 1 (reference) \\
\hline From inside the home only & 7546 (14.3) & 12.8 & $1.19(1.10 \text { to } 1.28)^{\star \star \star}$ & $1.16(1.07 \text { to } 1.25)^{\star * *}$ \\
\hline From neighbours only & $5230(10.5)$ & 12.4 & $1.20(1.10 \text { to } 1.31)^{\star \star \star}$ & $1.20(1.11 \text { to } 1.31)^{\star * *}$ \\
\hline From both & $2375(4.4)$ & 18.5 & $1.79(1.60 \text { to } 2.00)^{\star \star \star}$ & $1.74(1.56 \text { to } 1.94)^{\star \star *}$ \\
\hline Any source & $15151(29.2)$ & 13.5 & $1.28(1.21 \text { to } 1.36)^{\star \star \star}$ & $1.26(1.18 \text { to } 1.34)^{\star \star \star}$ \\
\hline
\end{tabular}


similar exposure doses, thus having comparable odds of respiratory symptoms. For SHS exposure from both sources, mostly reported by students in smoking families (95.2\%), a stronger association with respiratory symptoms was found. Under the influence of smokers at home, the students might have had a more positive attitude towards SHS and perceived themselves to be less vulnerable to the harms of SHS, showing less SHS avoidance. $^{26-28}$ They might then have more SHS exposure and higher odds of respiratory symptoms.

Our findings have provided new evidence of SHS exposure at home from neighbours and its association with respiratory symptoms in adolescents. Future investigation on and protective measures against home SHS exposure in children and adolescents should take neighbour SHS into consideration. In Hong Kong, the only smoke-free housing policy is the penalty point allotment to residents who smoke or carry a lighted cigarette in common areas in public rental housing, and tenancy will be terminated when certain points have been accrued. ${ }^{17}$ Research has shown that such a partial smoke-free housing policy could not protect the non-smoking families from SHS and might increase the likelihood of SHS transfer from smoking to non-smoking homes. ${ }^{29}$ In our survey, $14.0 \%$ of never-smokers living in public housing were exposed to neighbour SHS, in which $15.0 \%$ reported respiratory symptoms, further indicating the susceptibility of children and adolescents to SHS at home in housing with a partial smoking ban. Comprehensive smoke-free legislation covering shared areas and personal homes should be implemented in all residential buildings. Although smokers may argue that their personal rights would be violated, many non-smokers, especially those with children, perceive the SHS incursion annoying and advocate the smoking ban, as reported in some Western studies. ${ }^{30-32}$ Compared with the spacious living in Western countries, the problems brought by neighbour SHS may be more obvious in the compact living in Hong Kong. Legislation against smoking at home, accompanied by health programmes promoting smoke-free homes and smoking cessation services, is needed. As Mainland China and many low income and middle income countries are building more multistorey and multiunit residential buildings such as Hong Kong, our results are also relevant to these countries.

Our study has several limitations. First, all data including own and family smoking status, SHS exposure and respiratory symptoms were self-reported. Although smoking is a sensitive issue, the anonymity and confidentiality emphasised during the survey encouraged the students to report the truth. The self-reported smoking status was cross-checked with any smoking in the past 30 days to reduce invalid responses in analysis regarding smoking status. For SHS exposure, although cotinine and nicotine measures can give objective measurements, the biomarkers cannot distinguish the sources and places of exposure, the key factors in this study. The neighbour SHS exposure reported by students in non-smoking families was consistent with the objective measurements in other studies, ${ }^{67}$ showing the validity of data on neighbour SHS exposure. However, the prevalence might be underestimated as students in smoking families who could not differentiate the SHS sources might tend to believe that the SHS was generated from smokers inside the home and under-report their exposure. The proxy of respiratory symptoms, persistent cough and phlegm, was obvious to adolescents and explicit in the question to avoid measurement error. Since respiratory symptoms were asked well before SHS exposure, reporting bias for symptoms due to the report of SHS exposure status seems improbable. The association between SHS exposure and respiratory symptoms observed in other studies also supported our data validity. ${ }^{18} 2124$ Second, some students might report persistent cough and phlegm due to reasons other than SHS exposure (eg, pulmonary diseases), and causal association could not be ascertained due to the cross-sectional design. However, students with respiratory symptoms were more likely to avoid SHS exposure to lessen the symptoms instead of increasing exposure deliberately. Our observed results may underestimate the association between SHS and respiratory symptoms. Finally, SHS exposure outside the home might affect respiratory symptoms in adolescents. However, further adjustment for the exposure had little effect on the associations studied, and hence the results were not shown.

\section{CONCLUSION}

On the basis of self-reported data, around one-fifth of adolescents in Hong Kong were exposed to SHS at home from neighbours, suggesting an underestimation of SHS exposure at home in studies ignoring the neighbour SHS. In never-smokers, respiratory symptoms were associated with SHS exposure from neighbours of a magnitude similar to that from inside the home. A stronger association was observed for SHS exposure from both sources. Our findings support a comprehensive smokefree housing policy to protect children and adolescents from harms of SHS at home.

Acknowledgements The authors thank all the schools and students for their participation.

Contributors LTL collected and analysed the data, interpreted the results, and drafted the initial manuscript. SYH, MPW and WSL designed and coordinated the study, conceptualised the analysis plan, interpreted the results, and reviewed and revised the manuscript. THL gave advice on the study design, analysis plan and analysis results interpretation, and reviewed and revised the manuscript. All the authors approved the submitted manuscript.

Funding This work was supported by the Food and Health Bureau, the Government of Hong Kong Special Administrative Region.

Competing interests None declared.

Ethics approval The Institutional Review Board of the University of Hong Kong/Hospital Authority Hong Kong West Cluster.

Provenance and peer review Not commissioned; externally peer reviewed.

Data sharing statement No additional data are available. 
Open Access This is an Open Access article distributed in accordance with the Creative Commons Attribution Non Commercial (CC BY-NC 4.0) license, which permits others to distribute, remix, adapt, build upon this work noncommercially, and license their derivative works on different terms, provided the original work is properly cited and the use is non-commercial. See: http:// creativecommons.org/licenses/by-nc/4.0/

\section{REFERENCES}

1. US Department of Health and Human Services. The health consequences of involuntary exposure to tobacco smoke: a report of the Surgeon General. Atlanta, GA: US Department of Health and Human Services, Centers for Disease Control and Prevention, Coordinating Center for Health Promotion, National Center for Chronic Disease Prevention and Health Promotion, Office on Smoking and Health, 2006:709.

2. Warren $\mathrm{CW}$, Jones NR, Peruga A, et al. Global youth tobacco surveillance, 2000-2007. MMWR Surveill Summ 2008;57:1-28.

3. King BA, Travers MJ, Cummings KM, et al. Secondhand smoke transfer in multiunit housing. Nicotine Tob Res 2010;12:1133-41.

4. Spengler JD. Buildings operations and ETS exposure. Environ Health Perspect 1999;107:313-17.

5. Koster B, Brink AL, Clemmensen IH. 'Neighbour smoke'-exposure to secondhand smoke in multiunit dwellings in Denmark in 2010: a cross-sectional study. Tob Control 2013;22:190-3.

6. Kraev TA, Adamkiewicz G, Hammond SK, et al. Indoor concentrations of nicotine in low-income, multi-unit housing: associations with smoking behaviours and housing characteristics. Tob Control 2009;18:438-44.

7. Wilson KM, Klein JD, Blumkin AK, et al. Tobacco-smoke exposure in children who live in multiunit housing. Pediatrics 2011;127:85-92.

8. Fu M, Martinez-Sanchez JM, Galan I, et al. Variability in the correlation between nicotine and PM2.5 as airborne markers of second-hand smoke exposure. Environ Res 2013;127:49-55.

9. Information Services Department. Hong Kong: The facts. Population. Hong Kong: Information Services Department, 2013. (cited 23 October 2013) http://www.gov.hk/en/about/abouthk/factsheets/docs/ population.pdf

10. Chan EH, Tang BS, Wong WS. Density control and the quality of living space: a case study of private housing development in Hong Kong. Habitat Int 2002;26:159-75.

11. Rector R. How poor are America's poor? Examining the "Plague" of poverty in America. Backgrounder 2007;2064:7.

12. Wong SK, Wai-Chung Lai L, Ho DCW, et al. Sick building syndrome and perceived indoor environmental quality: a survey of apartment buildings in Hong Kong. Habitat Int 2009;33:463-71.

13. Tobacco Control Office. Tobacco control legislation. Hong Kong: Tobacco Control Office, 2012. (cited 17 September 2013) http://www.tco.gov.hk/english/legislation/legislation sa.html

14. Ho SY, Wang MP, Lo WS, et al. Comprehensive smoke-free legislation and displacement of smoking into the homes of young children in Hong Kong. Tob Control 2010;19:129-33.

15. Neighbour secondhand smoke. No ways to lodge complaints. Hong Kong: Apply Daily, 1 July 2012. Chinese. (cited 28 December 2013) http://hk.apple.nextmedia.com/supplement/service/art/20120701/ 16474054

16. Hong Kong Housing Authority. Housing in figures 2013. Hong Kong: Hong Kong Housing Authority, 2013. (cited 28 December 2013) https://www.housingauthority.gov.hk/en/common/pdf/about-us/ publications-and-statistics/HIF.pdf

17. Hong Kong Housing Authority. Marking Scheme for Estate Management Enforcement. Hong Kong: Hong Kong Housing Authority, 2012. (cited 14 September 2013) http://www. housingauthority.gov.hk/en/public-housing/estate-management marking-scheme-for-estate-management-enforcement/index.html

18. Lai HK, Ho SY, Wang MP, et al. Secondhand smoke and respiratory symptoms among adolescent current smokers. Pediatrics 2009;124:1306-10.

19. Lam TH, Chung SF, Betson CL, et al. Respiratory symptoms due to active and passive smoking in junior secondary school students in Hong Kong. Int J Epidemiol 1998;27:41-8.

20. Group GC. A cross country comparison of exposure to secondhand smoke among youth. Tob Control 2006;15(Suppl 2): ii4-19.

21. He QQ, Wong TW, Du L, et al. Environmental tobacco smoke exposure and Chinese schoolchildren's respiratory health: a prospective cohort study. Am J Prev Med 2011;41:487-93.

22. Wang CP, Ma SJ, Xu XF, et al. The prevalence of household second-hand smoke exposure and its correlated factors in six counties of China. Tob Control 2009;18:121-6.

23. Kabir Z, Connolly GN, Alpert HR. Secondhand smoke exposure and neurobehavioral disorders among children in the United States. Pediatrics 2011;128:263-70.

24. Cook DG, Strachan DP. Health effects of passive smoking. 3. Parental smoking and prevalence of respiratory symptoms and asthma in school age children. Thorax 1997;52:1081-94.

25. Dalton $\mathrm{P}$. Upper airway irritation, odor perception and health risk due to airborne chemicals. Toxicol Lett 2003;140-141:239-48.

26. Li MF, Wang RH. Factors related to avoidance of environmental tobacco smoke among adolescents in southern Taiwan. J Nurs Res 2006;14:103-12.

27. Martinelli AM. Testing a model of avoiding environmental tobacco smoke in young adults. Image J Nurs Sch 1999;31: 237-42.

28. Wang WL, Herting JR, Tung YY. Adolescents' avoidance of secondhand smoke exposure: model testing. Western J Nurs Res 2008;30:836-51.

29. Wilson KM, Torok M, McMillen $\mathrm{R}$, et al. Tobacco smoke incursions in multiunit housing. Am J Public Health 2014;104:1445-53.

30. Hewett MJ, Ortland WH, Brock BE, et al. Secondhand smoke and smokefree policies in owner-occupied multi-unit housing. Am J Prev Med 2012;43(5 Suppl 3):S187-96.

31. Hewett MJ, Sandell SD, Anderson J, et al. Secondhand smoke in apartment buildings: renter and owner or manager perspectives. Nicotine Tob Res 2007;9(Suppl 1):S39-47.

32. King BA, Cummings KM, Mahoney MC, et al. Multiunit housing residents' experiences and attitudes toward smoke-free policies. Nicotine Tob Res 2010;12:598-605. 